\title{
THE LINKAGE BETWEEN GEOLOGICAL SETTING AND HUMAN HEALTH IN ETHIOPIA: A PRELIMINARY GEO-ENVIRONMENTAL-HEALTH MODEL
}

\author{
Seifu Kebede \\ Department of Earth Sciences, Faculty of Science, Addis Ababa University, PO Box 1176 \\ Addis Ababa, Ethiopia. E-mail: seifukebede@yahoo.com
}

\begin{abstract}
Tropical environments are known for their prevalence of a number of geo-chemical diseases. This is related to the very nature of their geo-environments. Little research is conducted in geo-sciences in Ethiopia to investigate the linkage between geo-environments and associated health risks. Fluoride and related diseases are the most widely studied from geological perspectives. Ethiopia is characterized by complex but regionally homogeneous geo-environment. Climate is under the influence of monsoon from two oceans and continental sources. Locally orography modifies the redistribution of rainfall in the lee and wind ward directions. This leads to any combination of warm to cold and wet to dry climate. Prominent geologic features are rifting, volcanism and uplifting. Combination of geology, climate, and topography results in a complex pattern of geo-environment which in turn results in belts of availability or scarcity of certain geochemical elements. This work shows the presence of linkage between geo-environmental setting and prevalence of geo-chemical diseases such as goiter, elephantiasis, flourisis, and trace element related health problems. South-western Ethiopia, which is under the influence of Indian Ocean monsoon and underlain by volcanic rocks shows the highest incidence of Iodine Deficiency Disorder (IDD). Regions of Ethiopia under the influence of Atlantic Ocean monsoon or areas underlain by sediments and sedimentary rocks show the lowest IDD. Elephantiasis prevalence is linked to laterite soils derived from chemical weathering of basalts, a typical process commonly taking place in humid plateau of south-western Ethiopia between altitudes of 1000 and 2000 masl. Flouride related diseases are common features in area where water supply for domestic water use depend on aquifers in acid volcanic rocks, commonly in the rift setting. Regardless of the prevalence of geo-chemical diseases, Ethiopia is also endowed with natural geo-chemical materials of significant health benefits (e.g., Mineral waters and mud volcanoes). The work proposes a preliminary geo-environmental health model for Ethiopia.
\end{abstract}

Key words: Geochemical diseases, geo-environmental setting, Ethiopia, health belts

\section{INTRODUCTION}

At least 20 million people are affected or are at risk from toxic fluoride; at least two percent of populations in some sectors of Ethiopia are affected by elephantiasis and 20 million inhabited areas with risk of elephantiasis contraction. In affected areas prevalence rate may reach up to five percent of the general population. According to ministry of health and UNICEF report in 1993, 42 million people $(78 \%)$ of the total population of Ethiopia are exposed to iodine deficiency, 35 million (62\%) are iodine deficient, 14 million $(26 \%)$ have goiter and at least one in 1000 people is cretin; with about 50,000 prenatal deaths. All these non communicable diseases are affecting the physical, mental, socio cultural and economic status of the individuals and the country.

Except for fluoride whose spatial distribution is well documented and whose geological origin is well investigated from the earth sciences and medical disciplines in Ethiopia (Kilham and
Hecky, 1973; Ashley and Bruley, 1994; Gezahegn Yirgu et al., 1999; Tesfaye Cherenet et al., 2001; Reimann et al., 2003); the relation between the other two diseases and geological or geochemical processes is not well investigated.

Ethiopia is characterized by unique condition which leads to the prevalence of most of the geochemistry related tropical diseases. For examples the geology of Ethiopia is characterized by rifting, uplifting and volcanism. There is marked seasonality in rainfall (clear wet season and followed by clear dry season). The topography is very complex with mountain peaks intervening with deep gorges. Complex rainfall regime with monsoon dominated rainfall in some sectors, orographic rainfall in others and rain shadow effects in lowlands.

This unique nature of the geology, topography, and climate should lead to a marked variation belts in abundance and or deficiency of certain geo-chemical elements in the environment. For examples fluoride, arsenic, uranium and other 
mobile trace elements are the most abundant in rift setting. Iron, Manganese, and immobile trace elements dominate soils in the areas dominated by monsoon precipitation.

This preliminary work is the first attempt to investigate the relation between geo-chemistry related diseases and the geo-chemical, geological and climatic processes in Ethiopia at a regional spatial scale. In doing so the paper attempts to predict vulnerable areas for the prevalence of the diseases. Five principal geo-chemistry related health issues will be addressed. These are goiter; elephantiasis; fluorisis; mineral waters; and emerging health risks associated with arsenic and uranium.

\section{GEO-ENVRIONMENTAL AND GEO- CLIMATIC SETTING}

Ethiopia is marked by its remarkable variations in geology (rifting, massive outpouring of volcanic rocks, uplifting to several thousand meters above sea level), topography (narrow constricted valleys intervening with mountain peaks); climate (deserts, humid topical climate) and rainfall derivation (monsoon and orography interacting rainfall derivation). All these remarkable variability in geo-environmental conditions should result in geographic variation in geo-chemical elements.

South-western Ethiopia is under the influence of the monsoon climate whose moisture is derived from the Congo vegetation and the Atlantic Ocean (Tato Kebede, 1964; Daniel Gemechu, 1977). This is also supported by stable isotope studies in meteoric waters across Africa and Ethiopia (Rozanski et al., 1996; Seifu Kebede, 2004). South-eastern Ethiopia is under the influence of the Indian Ocean moisture rainfall which represents the first condensate from ocean derived vapor. Rainfall amount decreases northward as one moves from the south-western lowlands.

Around two third of Ethiopia is covered by volcanic rocks (basalts and rhyolites). By geochemical classification the volcanic rocks from Ethiopia are dominantly transitional and tholeitic (Pik et al., 1998; Dereje Ayalew et al., 1999). Basalts and rhyolites of northern and southern part of the north-western plateau show some compositional difference as measured by their titanium oxide abundance. In the southern part the volcanic rocks contain relatively higher titanium oxide (Pik et al., 1998; Dereje Ayalew et al., 1999). Furthermore in south-western low- lands and mid altitude areas, the volcanic rocks directly overly the Precambrian metamorphic basement.

The remaining part of the country is underlain by metamorphic and sedimentary rocks. Sedimentary rocks crop out in the Blue Nile gorge, in the Tigray plateau and in the southeastern part of the country. In the rift, which divides Ethiopia into two, lacustrine sediments cover the volcanic rocks. Compared to the highlands, the rift is also known for abundance of evolved volcanic materials such as ignimbrites and rhyolites which contain abundant trace elements.

Highly leached iron, aluminum and silica-rich red soils dominate the south-western and northwestern lowlands of Ethiopia. In the northern part of the north-western plateau (e.g., Shoa, Gojam and Gondar plateaus) black cotton soils dominate.

\section{METHODS AND DATA}

Spatial plotting of the geo-chemical diseases has been conducted in order to investigate if there is linkage between regional geo-environmental setting and the diseases.

Data on goiter prevalence in Ethiopia have been obtained from the World Health Organization (WHO) database http://www.who.int/vmnis/iodine/data/database accessed on 05 May 2009. The goiter prevalence data do not have geographic coordinate so efforts have been used to find the real locations of the sites using other available maps. GIS maps of towns of Ethiopia, Woreda maps of Ethiopia, and topographic maps at the scale of 1:250000 have been used for the purpose. In doing so the exact geographic coordinates for more than 95 percent of the locality names indicated in the WHO data base have been retrieved. In cases where more than one geographic location is possible for a locality name, the data have not been used.

In investigating the elephantiasis prevalence simple field observation by the author has been used. Previous observation on prevalence of elephantiasis (Price, 1974; 1976) has also been used.

For arsenic and uranium variation distribution maps in Ethiopia 18 ground water samples have been collected from central Ethiopia between Addis Ababa and Metahara. Table 1 shows the concentration of trace elements in the groundwaters along the Addis Ababa-Lake Beseka transect. 
Table 1. Trace element concentration of groundwaters from wells distributed between Addis Ababa and Lake Beseka, concentration in ppb.

\begin{tabular}{|c|c|c|c|c|c|c|c|c|c|c|c|}
\hline Location & $\begin{array}{l}\text { Temperature } \\
\left({ }^{\circ} \mathrm{C}\right)\end{array}$ & $\mathrm{EC}$ & $\mathrm{pH}$ & $\mathrm{F}$ & $\mathrm{Li}$ & B & Mo & As & $\mathrm{U}$ & $\mathrm{Sr}$ & Mn \\
\hline Sebeta & 18.6 & 233 & 6.97 & 0.40 & 5.34 & 9.70 & 0.73 & 0.39 & 0.31 & 132.80 & 1.16 \\
\hline Filwuha & 59.0 & 4270 & 7.32 & 24.34 & 281.00 & 323.00 & 21.27 & 50.09 & 0.01 & 123.50 & 3.39 \\
\hline Akaki EP7 & 23.0 & 575 & 7.60 & 0.38 & 1.48 & 29.66 & 2.58 & 0.50 & 2.54 & 419.80 & 0.54 \\
\hline Dukem & 26.7 & 620 & 7.26 & 0.31 & 6.27 & 22.93 & 1.001 & 0.48 & 2.48 & 475.70 & 1.91 \\
\hline Debrezeit & 24.2 & 532 & 7.29 & 0.49 & 3.33 & 23.38 & 2.19 & 0.77 & 2.30 & 353.70 & 0.53 \\
\hline Jimjima & 24.0 & 565 & 7.24 & 0.91 & 13.51 & 43.65 & 4.27 & 1.90 & 4.55 & 314.80 & 0.06 \\
\hline Tede & 26.8 & 423 & 8.09 & 1.03 & 20.27 & 45.45 & 4.13 & 1.01 & 5.15 & 134.30 & 0.42 \\
\hline Chemer Jaw & 28.9 & 476 & 7.66 & 1.56 & 26.65 & 49.54 & 4.86 & 1.82 & 6.00 & 210.90 & 1.23 \\
\hline Abu Diab & 27.5 & 500 & 7.24 & 1.31 & 22.53 & 52.27 & 3.70 & 1.72 & 10.10 & 172.70 & 0.86 \\
\hline Nazareth & 34.0 & 570 & 7.52 & 1.32 & 28.36 & 65.40 & 12.06 & 2.04 & 3.23 & 79.57 & 0.53 \\
\hline Wolenchit & 33.0 & 620 & 7.62 & 2.25 & 23.27 & 162.10 & 18.49 & 4.83 & 3.11 & 171.90 & 0.03 \\
\hline Borcheta & 36.7 & 1300 & 8.32 & 5.70 & 18.62 & 346.90 & 56.10 & 22.49 & 7.80 & 44.95 & 2.27 \\
\hline Ebilti Besek & 33.9 & 1775 & 8.41 & 4.96 & 27.29 & 887.80 & 89.74 & 15.11 & 8.81 & 121.30 & 0.15 \\
\hline Keseme ket & 50.1 & 2010 & 7.96 & 5.52 & 67.38 & 1088.00 & 81.30 & 26.39 & 5.80 & 60.65 & 0.05 \\
\hline Keseme ket & 37.0 & 1927 & 8.23 & 3.75 & 62.97 & 1069.00 & 79.70 & 25.67 & 6.20 & 47.97 & 2.72 \\
\hline Gefersa sew & 21.1 & 242 & 6.60 & 0.20 & 7.34 & 8.44 & 0.30 & 0.38 & 0.02 & 130.10 & 1.19 \\
\hline Meki & 27.0 & 658 & 8.16 & 6.12 & 15.67 & 63.05 & 14.29 & 16.62 & 3.91 & 39.75 & 0.41 \\
\hline
\end{tabular}

EC, .electrical conductivity

Furthermore iodine concentration in ground waters has been measured across the shoulder of the rift (Seifu Kebede, 1999; Table 2). The repeated analyses have been done in 1999 at the University of Wales, Department of Geography using ICPMS. In addition, extensive data set including trace element concentration in
Ethiopian rift groundwaters collected and analyzed by Reimann et al. (2003) has been used in this work.

Geothermal waters, soda springs and mud volcanoes which are believed to have therapeutic values and direct health consequences has been mapped from field evidences.

Table 2. Bromide and iodine concentration in goundwaters from the Western shoulder of the Ethiopian Rift (Debrezeit), concentration in ppb.

\begin{tabular}{|c|c|c|c|}
\hline Sample code & Location & $\mathrm{Br}$ & $\overline{\mathrm{I}}$ \\
\hline$\overline{28}$ & CIM BW & 27.7 & 9.2 \\
\hline 33 & Hora BW & 63.4 & 10.1 \\
\hline 35 & West/north cheleleka, north, shore & 5.4 & 50.8 \\
\hline 37 & Hora Tannary, BW & 54.2 & 23.7 \\
\hline 38 & Kalehiwot Church Eastern BW & 40.0 & 59.4 \\
\hline 39 & Almaz Doro Bw & 71.7 & 102.8 \\
\hline 44 & Kalehiwot Church Southern BW & 769.5 & 1659.6 \\
\hline 45 & Almaz Doro, Bw & 22.6 & 58.9 \\
\hline 46 & East Cheleleka & 4.3 & 108.7 \\
\hline 47 & Hora Tannary BW & 76.7 & 20.8 \\
\hline 57 & Elfora BW & 27.8 & 16.8 \\
\hline 58 & Hora Tannary BW & 140.0 & 22.9 \\
\hline 59 & AdaPasta\&mac. BW & 70.5 & 44.5 \\
\hline 60 & Agri Res.Center East BW & 125.5 & 38.8 \\
\hline 61 & N.FrancoBW & 711.4 & 700.8 \\
\hline 62 & Agri Res Inst. BW & 122.1 & 579.5 \\
\hline 63 & Management inst BW & 131.0 & 27.3 \\
\hline 64 & Defence Eng. BW2 & 38.3 & 45.5 \\
\hline 65 & Defence Eng BW & 548.4 & 1232.9 \\
\hline 66 & Dragados BW & 34.9 & 5.9 \\
\hline 67 & BlueNilePF BW & 55.4 & 27.4 \\
\hline 68 & HoraAgrolnd.BW & 74.9 & 143.9 \\
\hline 69 & AlmazDoro BW & 88.6 & 30.7 \\
\hline 70 & Slaught House BW & 324.4 & 28.7 \\
\hline 71 & Kalehiwot Church tap & 146.6 & 12.7 \\
\hline 72 & Kalehiwot East BW & 144.4 & 140.0 \\
\hline 73 & Ato Gizaw HDW & 1626.8 & 1271.9 \\
\hline 20 & CIM-mission BW & 83.7 & 10.7 \\
\hline 21 & Almaz Doro BW & 12.1 & 34.8 \\
\hline 22 & Debrezeit & 2.6 & 5.6 \\
\hline
\end{tabular}




\section{RESULTS AND DISCUSSION}

\section{Iodine vs. iodine deficiency disorder}

Geo-environmental sources of iodine

Sea water with a mean concentration of $58 \mathrm{ppb}$ of iodine is the most important reservoir for terrestrial iodine and this markedly influences the distribution of iodine in the secondary environment (Fuge and Johnson, 1986). Marine carbonate and sedimentary rocks contain iodine ranging from 2.5 to $30 \mathrm{ppm}$ (Dissanayake and Chandrajith, 1999). Ground and surface waters are among the most important media that act as a bridge between rock, rainwater and soil geochemistry and human physiology (Dissanayake and Chandrajith, 1999). In Ethiopian groundwaters iodine concentration is lower than the marine values.

\section{Iodine deficiency disorder}

Lack of adequate iodine in food and drinking water could lead to Iodine Deficiency Disorder (IDD). This causes goiter, cretinism, poor pregnancy, still birth, mental retardation and infant mortality (MOH-UNICEF, 1995). Iodine deficiency is the world's most common cause of mental retardation and brain damage and goiter incidence (Dissanayake and Chandrajith, 1999).

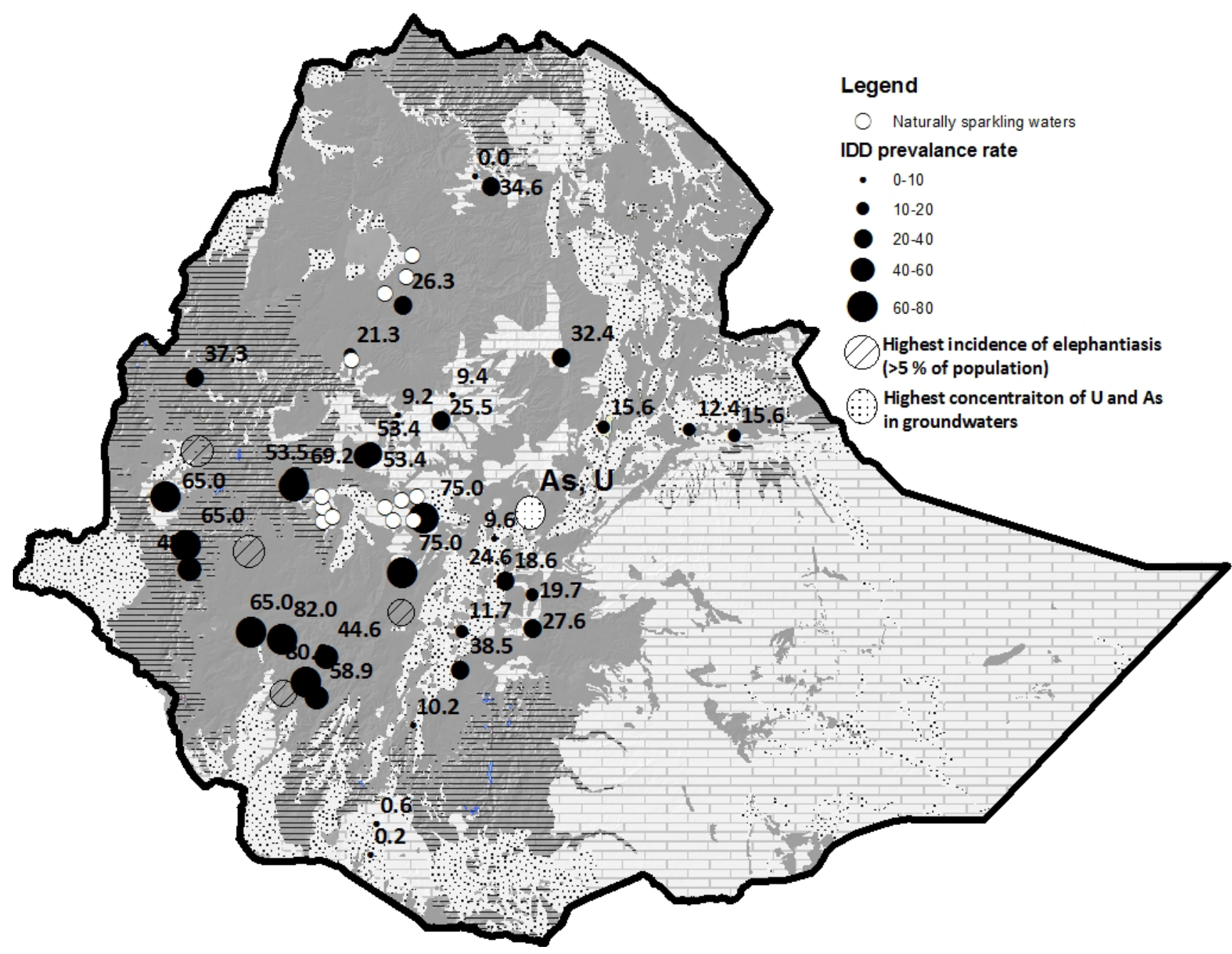

Fig. 1. Map showing observed incidence of goiter and elephantiasis in Ethiopia.

(Numbers near black circles indicate goiter prevalence rate, note that the size of the circle corresponds to prevalence rate. Data on goiter prevalence from WHO database accessed at: http://www.who.int/vmnis/iodine/data/database.) 
Causal mechanism of Iodine deficiency vs. geoenvironmental setting

Figure 1 shows spatial pattern of goiter prevalence rate in Ethiopia. The following information can be drawn from the spatial correlation. Medical sciences research in Ethiopia have previously recognized that risks of IDD is associated with: a) living in high altitudes; b) cassava and millet consumption; and c) leaching of iodine from top soil by erosion and flooding (MOH-UNICEF, 1995). However none of these works show the underlying mechanism of iodine enrichment and depletion with the geoenvironmental setting. Two regions of Ethiopia with similar altitude (i.e., the north-western plateau and south-eastern plateau) show different degrees of prevalence in goiter (Fig. 1). Therefore, altitude alone can not be the underlying mechanism of high incidence of goiter. The correlation between goiter prevalence and geo-environmental setting at regional scale leads to drawing up of the following hypothesis for the casual mechanism of iodine deficiency.

Comparison between the iodine concentrations of groundwaters from the two data sets shows (Table 2 vs. Fig. 3 in Reimann et al., 2003) that high concentration of iodine is observed in the rift center than in the adjacent plateaus or escarpments. The highest iodine content are specifically observed in groundwaters from deepest wells, in wells from Borena lowlands, the central part of the rift around Nazareth and in the Afar depression. Except in deep groundwaters and groundwaters associated with lacustrine sediments. Iodine concentration in groundwaters of the western plateau is lower than that of sea water. This suggests the modification of ocean moisture by iodine deficient continental vapor input from Congo vegetation as already suggested by Rozanski et al. (1996) playing role in diluting the iodine content of moisture directly coming from the Atlantic Ocean.

- Goiter prevalence is significantly lower in the lowlands of Borena and the rift valley, both regions known for their high salt content in the groundwaters owing to evaporative enrichment of groundwaters prior to recharge and salt dissolution from lacustrine sediments. Iodine concentration in groundwaters of the rift is also higher than global average and than the marine concentration owing to diffusion of trace gases from the mantle through rift faults.

- The highest goiter prevalence is observed in south-western Ethiopia which is under the influence of the south-westerly monsoon driving its moisture from the Atlantic Ocean and the advective moisture engulfed from the Congo vegetated basin. The dilution of the marine moisture by advected moisture from the Congo vegetation should be responsible for depletion of iodine in the monsoon rains. Furthermore the high rainfall intensity and associated strong leaching of the rocks could lead to elimination of iodine from availability (as groundwaters or biologically).

- In south-eastern Ethiopia goiter prevalence is lower. The region is under the influence of the Indian Ocean moisture which because of short moisture trajectory could contain higher amount of marine iodine. The survey by Reimann et al. (2003) also shows high concentration of iodine in groundwaters from the Harar and Arsi plateau bordering the rift. The marine sediments dominating the southeastern Ethiopian region contribute also to lower prevalence of goiter.

- On the north-western Ethiopian plateau, goiter prevalence generally decreases from south to north. Rainwater collected from these sectors of Ethiopia show a northward increase in salinity (Seifu Kebede, 2004) owing probably to admixture of dust and aerosols derived from the Sahel and Arabian continent. The decrease in goiter prevalence could be related to increase in salinity of rainfall. Furthermore the northern part of the north-western plateau covered by Mesozoic marine sequences (Fig. 1) becomes important. This could directly or indirectly contribute to the natural availability of iodine in the environment.

- Variation in goiter prevalence in a single geoclimatic zone generally increases with increase in altitude. For example, data from altitudinal transect in Wag Hmrah shows that goiter prevalence is higher in highlands than in lowlands (Fig. 1). This being related to increase in salinity of groundwaters owing to higher evaporation in the lowlands and absence of such a process of salt enrichment in highland. 
The highland of the Wag Hmrah is underlain by basaltic rocks while the lowlands are underlain by Mesozoic sediments. The variation in geology and salinity of groundwater across the altitude transect is the main controlling mechanism of goiter prevalence in this region of Ethiopia.

\section{Immobile trace elements, red soils and elephantiasis}

Agent of elephantiasis

Widely mentioned (e.g., Price, 1974) and possible cause of elephantiasis in Ethiopia is related to the red soil on which certain barefooted populations live. It is believed that small chemical particles (aluminium, silicon, titanium and iron oxides) found in the soil may enter the skin through the bare feet. These particles then lodge in the lymphatic tissues and produce irritating effects. The traumatized tissue is then vulnerable to streptococcal infection.

\section{Non filarial elephantiasis}

Non filarial elephantiasis is non infectious swelling of the feet (Price, 1974).

\section{Elephantiasis prevalence in Ethiopia}

Elephantiasis is common disease in all sectors of Ethiopia. However previous reports (Price, 1974; 1976) and field observation by the author shows that the hot spots are located in Wolaita area, Dimbidolo, Wolegga, Upper Ghibe valley, and the south-western midland extending from southern Ethiopia to Metema in the north. Elephantiasis is common in red soil covered areas of Woinadega climate and the incidence drops significantly as one moves out of the red soil covered areas (Fasil Tekola, 2005).

\section{Causal mechanism of elephantiasis in Ethiopia}

Apparently little research in earth sciences discipline is conducted as to investigate the correlation between volcanic rock geo-chemistry and elephantiasis prevalence. Despite this at the scale of African continent, correlation has been noted to exist between alkali basalt provinces and elephantiasis prevalence (Harvey et al., 1996). It is widely mentioned extensive weathering of alkaline basalts yield particles of size less than 5 micrometer. These particles are responsible for blockage of lymph. Microanalyses of particles from elephantiasis affected tissue show that particles are composed of $\mathrm{Si}, \mathrm{Al}, \mathrm{Ti}$ and Fe (Price, 1974).

Regardless of the extensive research in geochemistry of volcanic rocks in Ethiopia the detailed investigation of the correlation between basalt geo-chemical variation in Ethiopia and elephantiasis prevalence remains unclear. However the preliminary elephantiasis prevalence map in Ethiopia (Fig. 1) shows no apparent correlation between regional variations in volcanic rock geo-chemistry. In contrast to the suggestion made by Harvey et al. (1996) that elephantiasis prevalence correlation with alkaline basalt domains, basalts in elephantiasis prevalent area of Ethiopia are transitional or tholeitic in their mineralogy (Pik et al., 1998; Dereje Ayalew et al., 1999). This may suggest basalt geochemistry alone may not be responsible but degree of weathering should be responsible. However there is a clear correlation between temperature, rainfall amount, altitude, rock type and soil type and elephantiasis prevalence. The most prevalent areas correspond to intensive monsoon rain, highly leached laterite soils, high temperature, altitude varying between 1000 and 2000 meters and volcanic rock cover. All this combination leads to the formation of thick red brown kaolinitic soil rich in $\mathrm{Fe}, \mathrm{Ti}, \mathrm{Si}$ and $\mathrm{Al}$. The typical geo-chemical reaction which may lead to higher $\mathrm{Fe}, \mathrm{Ti}, \mathrm{Si}$ and $\mathrm{Al}$ in soils is shown in Fig. 2.

\section{Arsenic, uranium and other mobile trace elements an emerging health issue}

Hazards from excess arsenic, uranium and other mobile trace elements

Excess arsenic in the environment particularly in groundwaters is becoming a global health concern. Excess arsenic intake is commonly associated with skin and internal cancer, melanosis, keratosis, and death. The maximum allowable limit of arsenic in drinking water is set at 10 micrograms/per milliliter by World Health Organisation (WHO, 2006). Surveys by Seifu Kebede (1999) in groundwaters of Debrezeit, by Reimann et al. (2005) in the entire rift valley of Ethiopia, and by Seifu Kebede et al. (2010) in central Ethiopia show significant number of water points in Ethiopian rift return excess As and enriched trace element composition compared to the WHO (2006) standard. Table 1 shows mobile trace element data from the central 
Ethiopia rift. Around thirty percent of drinking water sources from groundwater samples across the central Ethiopia show excess As, twenty percent show excess Mo (exceeding 70 microgram/ milliliter of WHO, 2006) or B (exceeding 500 micrograms/milliliter of WHO, 2006).

\section{Causal mechanisms of excess trace elements}

Excess trace element composition in groundwaters of the rift valley above the global average value is related mostly to leaching of geothermal systems of the rift (Reimann et al., 2003; Seifu Kebede et al., 2010). The highest concentration of $A s$ and $U$ is observed in the central part of the rift where deeper regional groundwater flow paths are recognized. An investigation by Seifu Kebede et al. (2010) shows that the enrichment of the trace elements is related to the nature of geo-chemical environment of the rift. In the rift because of rarity of organic matter in the rocks the subsurface groundwater environment is mostly in oxidizing conditions. This favors enrichment of heavy trace elements such as uranium in waters. The fact that there is a clear correlation between mobile trace elements and fluoride (Fig. 3) suggest that the elements have similar mode of enrichment and that integrated approach is needed in managing the health risk.

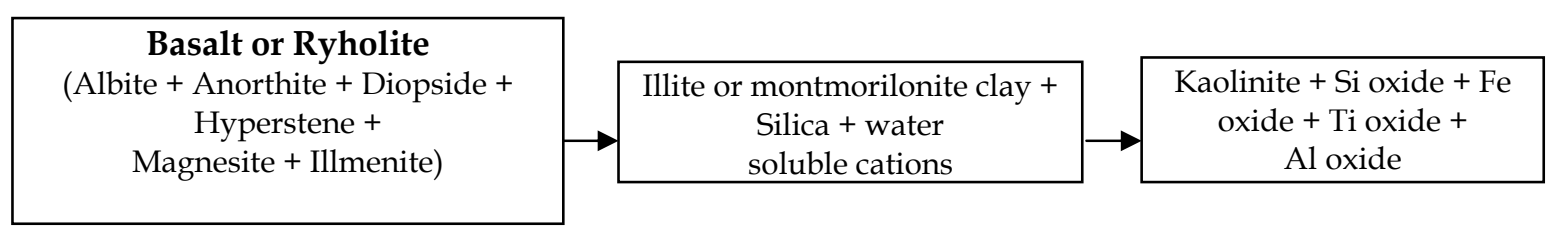

\section{Weathering degree increases}

Fig. 2. Geochemical reaction model for the enrichment of elephantiasis causing agents in volcanic terrains of Ethiopia. (Note that any volcanic rock with initial alkaline or tholeitic composition may produce similar weathering end members.)

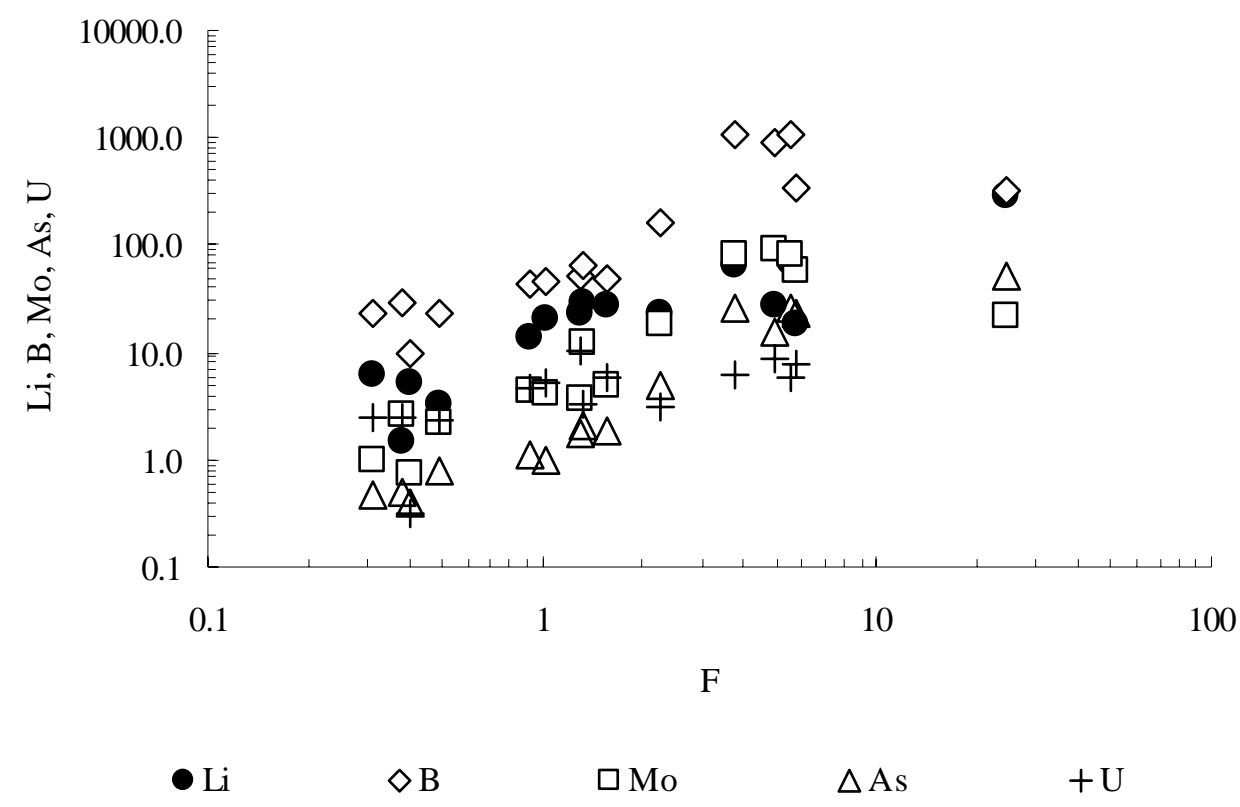

Fig. 3. Correlation between $\mathrm{F}$ and other mobile trace element concentration in groundwaters of the central part of Ethiopian rift. 
Impact on health of arsenic and other trace elements

Regardless of the excess arsenic, boron and molybdenum in some drinking water points the effect on health of the general public in Ethiopia is not known.

\section{Fluoride and fluorisis}

Dental and skeletal flourisis is a common health problem in the rift valley environment. The cause of fluoriss is excess fluoride. Excess fluoride comes from leaching of acid volcanic rocks containing alkaline minerals. Evaporative recycling of $\mathrm{F}$ in the environment also contributes towards enrichment of $\mathrm{F}$ in groundwaters. Unlike other geo-chemical health threats, detailed research has been conducted on sources of fluoride in the rift (Kilham and Hecky, 1973; Von Damm and Edmound, 1984; Ashley and Bruley, 1994; Birhanu Gizaw, 1996; Darling et al., 1996; Gezahegn Yirgu et al., 1999; Seifu Kebede, 1999; Tesfaye Chernet et al., 2001). A number of researches have been conducted on deflouridation techniques as well.

\section{Mineral waters and health}

\section{Myth and reality about mineral waters}

There is no standard definition of mineral water. The World Health Organization does not have a separate standard for mineral waters. Often, groundwaters which are naturally carbonated, sparkling, warm at point of emergence, contain balanced constituents of mineral species, and contain appreciable amount of trace elements are considered as mineral waters. Generally, mineral waters contain higher total dissolved solids. Unlike ordinary groundwaters naturally sparkling mineral waters contain most of the dissolved constituents at balanced and similar proportions. This is the result of $\mathrm{CO}_{2}$ joining the waters and keeping the mineral constituents in dissolved forms. Table 3 shows the chemical composition of an ordinary groundwater and a naturally sparkling mineral water. It can be seen that regardless of their similarity in overall total dissolved solids the sparkling water contain balanced composition of all major elements.

\section{Mineral waters and health}

Mineral waters by definition should provide balanced and rich elements for health. In normal waters, because of thermodynamic processes and separation of geo-chemical facies along groundwater flow paths, conditions are unfavorable to have similar abundance of each chemical element and rich mineral content. Ordinary groundwaters are rich in certain types of elements but not in others (e.g., higher in $\mathrm{Na}$ and $\mathrm{K}$ but negligible content of $\mathrm{Ca}$ and $\mathrm{Mg}$ ). The presence of rich and diverse chemical elements in mineral waters makes them suitable for human metabolic functions and health.

\section{Occurrence of naturally sparkling groundwater in Ethiopia}

Naturally sparkling groundwaters are rare world wide. A rare combination of geological and geo-chemical processes is responsible for the occurrence of mineral waters. This requires natural source of carbon dioxide from deeper sources, cold and shallow groundwaters circulating at shallow depths, heat from deeper geologic sources, etc. In Ethiopia such a combination occurs in regions surrounding the Wonchi volcano, and in the Lake Tana graben (Fig. 1). Some naturally sparkling groundwaters are also noted in the Didessa valley.

Table 3. Comparison of chemical composition of ordinary groundwater (OW) and naturally sparkling groundwaters (MW).

\begin{tabular}{lllllllllllll}
\hline Locality & $\mathrm{PH}$ & $\mathrm{TDS}$ & $\mathrm{K}$ & $\mathrm{Mg}$ & $\mathrm{Na}$ & $\mathrm{Ca}$ & $\mathrm{HCO}_{3}$ & $\mathrm{SO}_{4}$ & $\mathrm{Cl}$ & $\mathrm{F}$ & $\mathrm{NO}_{3}$ & $\mathrm{Type}$ \\
\hline Ambo & 6.7 & 1651.9 & 27.5 & 39.4 & 314.0 & 52.9 & 1159.0 & 13.0 & 42.5 & 0.5 & 2.6 & $\mathrm{MW}$ \\
Keseme kebena & 8.2 & 1445.3 & 34.2 & 0.4 & 335.7 & 2.1 & 786.0 & 69.8 & 108.8 & 3.8 & 1.5 & $\mathrm{OW}$ \\
\hline
\end{tabular}

Both (OW and MW) contain similar amount of total dissolved solids but the mineral waters show more balanced distribution of chemical constituents. Data from Seifu Kebede et al. (2005) and Seifu Kebede et al. (2010). 
While the high and balanced mineral content could be beneficial to health, the exact relation between public health and consumption of mineral waters is not clear in Ethiopia. However the public believes that such waters have healing effect from diseases.

\section{Geo-environmental model of geo-chemical diseases in Ethiopia}

Figure 4 depicts the relation between geological processes and geo-chemical diseases in Ethiopia. Figure 5 shows risk maps of geochemical diseases in Ethiopia. The maps have been constructed based on the observed disease prevalence, data and knowledge that exist on geo-chemistry, geology, climate, altitude and soil types of Ethiopia. By comparing the prevalence of geo-chemical diseases and the geo-environmental settings shown in Figure 4 geo-chemical health risk belts have been constructed (Fig. 5).
As a result of the unique nature of the Ethiopian geological settings both elephantiasis and higher goiter belts are found in common association in SW lowlands and mid-altitude regions. In other tropical settings, heavy monsoon rains generally contain higher iodine content leading to lower prevalence of goiter (Dissanayake and Chandrajith, 1999). The heavy monsoon rain in south-western lowlands and mid-altitude regions of Ethiopia derives part of its moisture from continental setting such as the Congo vegetation. Entrapment of marine iodine by the vegetation probably leads to depletion in the element in the monsoon rains of southwestern Ethiopia. Despite the suggestion that highlands are characterized by higher goiter prevalence, in SE Ethiopia, goiter prevalence is lower (Fig. 1). The characteristic pattern in the prevalence of geo-chemical diseases in Ethiopia is produced by a complex interaction of geology, soil formation processes, evaporation degree, rifting and topography.
Atlantic and Congo monsoon

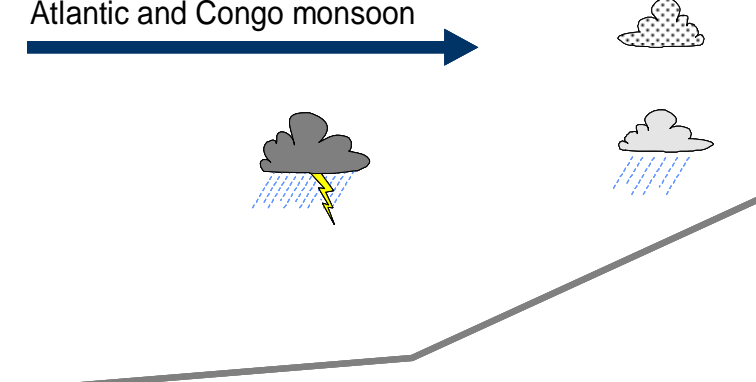

SW lowlands
NW highland

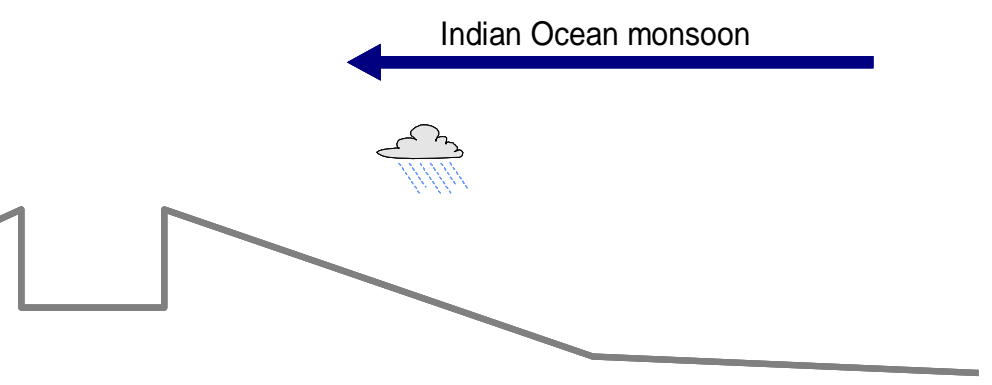

Indian Ocean monsoon

\begin{tabular}{|c|c|c|c|c|}
\hline $\begin{array}{l}\text { Warm; intensive chemical } \\
\text { weathering, altitude } 1000-2000 \\
\text { masl }\end{array}$ & $\begin{array}{l}\text { Cold; orographic rain; lower } \\
\text { degree of chemical } \\
\text { weathering; rain total dissolved } \\
\text { solids is higher }\end{array}$ & $\begin{array}{l}\text { Warm and dry, high } \\
\text { degre of } \\
\text { Evaporation }\end{array}$ & $\begin{array}{l}\text { Cold and wet, rain water dissolved solids is } \\
\text { higher because of proximity to the ocean } \\
\text { source }\end{array}$ & Temperature \\
\hline $\begin{array}{l}\text { Heavy monsoon, moisture from } \\
\text { Atlantic \& Congo vegetation, Low } \\
\text { lodine }\end{array}$ & $\begin{array}{l}\text { Influx of dust particles from } \\
\text { Sahel and Arabian continent, } \\
\text { rain with relatively higher I }\end{array}$ & $\begin{array}{l}\text { Low intensity } \\
\text { rainfall, rain } \\
\text { shadow effect }\end{array}$ & $\begin{array}{l}\text { Monsoon moisture from Indian Ocean, higher } \\
\text { lodine owing to proximity to moisture source; } \\
\text { rainfall amount lower than the NW plateau }\end{array}$ & Rainfall derivation \\
\hline $\begin{array}{l}\text { Highly leached, Fe, Al, Si reach } \\
\text { regoliths and red brown soils } \\
\text { dominate }\end{array}$ & $\begin{array}{l}\text { Black cotton soil dominate the } \\
\text { landscape, soils are thin on } \\
\text { higher grounds }\end{array}$ & $\begin{array}{l}\text { Salt reach, } \\
\text { regosols and } \\
\text { alluvio lacustrine } \\
\text { soils }\end{array}$ & Black cotton soils dominate the landscape & Soil \\
\hline Basalts and Metamorphic & $\begin{array}{l}\text { Basalts with marine sediments } \\
\text { in places }\end{array}$ & $\begin{array}{l}\text { Acid volcanic } \\
\text { rocks, basalts and } \\
\text { lacustrine } \\
\text { sediment, mantle } \\
\text { fluid influx }\end{array}$ & Basalts and marine sediments in some places & Geology \\
\hline $\begin{array}{l}\text { Prevalent Elephantiasis } \\
\text { Prevalent Goiter }\end{array}$ & $\begin{array}{l}\text { Less prevalent goiter in } \\
\text { intervening valleys and in } \\
\text { sediment covered areas, less } \\
\text { prevalent elephantiasis }\end{array}$ & $\begin{array}{l}\text { Less prevalent } \\
\text { goiter and } \\
\text { elephantiasis, } \\
\text { prevalent flourisis }\end{array}$ & $\begin{array}{l}\text { Less prevalent Goiter, lower prevalent } \\
\text { elephantiasis }\end{array}$ & $\begin{array}{l}\text { Geochemical } \\
\text { disease }\end{array}$ \\
\hline
\end{tabular}

Fig. 4. Schematic model of geochemical disease prevalence and geo-environmental setting in Ethiopia. 


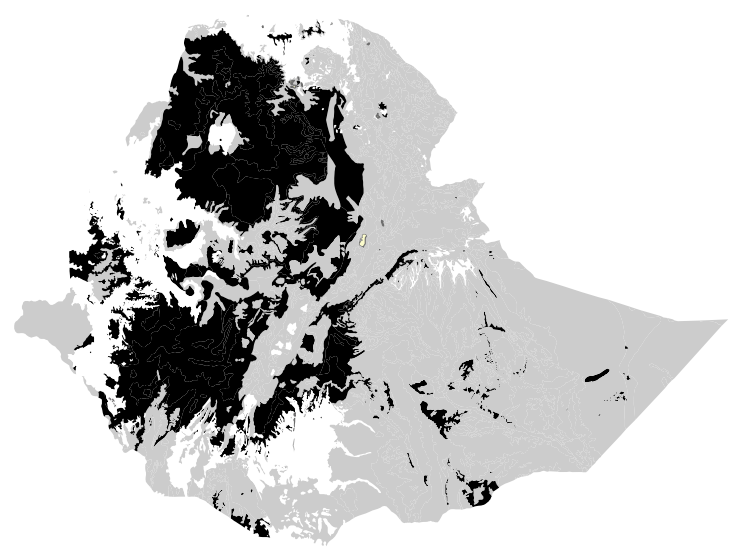

Goiter belt

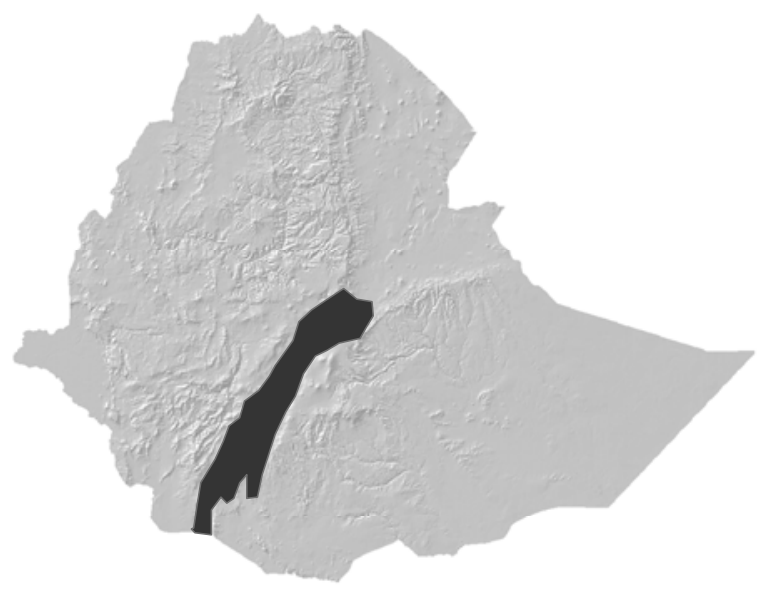

Fluorisis belt

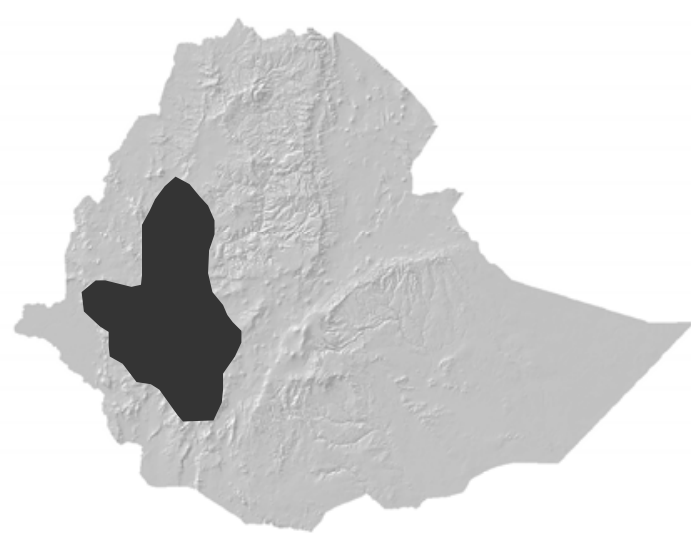

Elephantiasis belt

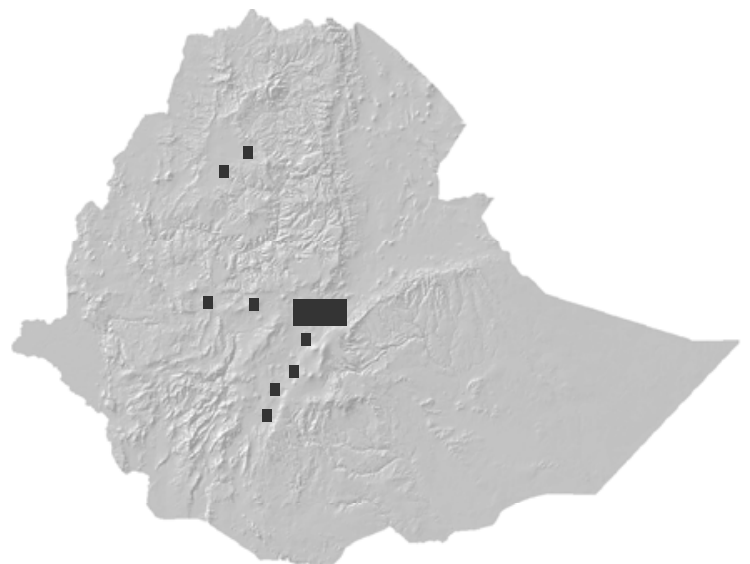

Excess As, U, Mo, B, Li related health risks

High risk

Low risk

No data

Fig. 5. Projected geochemical health risk belts in Ethiopia.

\section{GENERAL REMARKS AND CONCLUSIONS}

This preliminary work shows that the spatial variation in geo-chemical diseases in Ethiopia correlates well with regional variation in geoenvironmental setting. The geo-environmental disease model has been constructed based on limited data set particularly on groundwater trace element geo-chemistry, soil geo-chemistry, and rainwater geo-chemistry. A detailed research initiative may be needed to come up with a complete picture of the linkage between geochemical diseases and geo-environmental setting.

On the other hand further investigation is needed regarding the threats posed from high arsenic and uranium in central Ethiopia. A number of questions arise from this preliminary investigation such as:

1. What is does the iodine geo-chemical cycling within the Ethiopian terrain look like?

2. What is the effect of geo environmental setting on animal health?

To fully benefit from research at the interface between earth sciences and medical sciences in Ethiopia, prevalence of geo-chemical diseases needs to be documented according to geoenvironmental setting in place of administrative region based documentations. A better geoenvironmental health model and further research in the discipline would help health intervention 
initiatives such as the national iodization programs.

\section{ACKNOWLEDGMENTS}

Original data for this particular study have been obtained under the MAWARI project sponsored by the French Ministry of Foreign Affairs. Dr Dereje Ayalew, Department of Earth Sciences, Addis Ababa University is acknowledged for his comments on the manuscript.

\section{REFERENCES}

1. Ashley, R.P. and Bruley, M.J. (1994). Controls on the occurrence of fluoride in groundwater in the Rift Valley of Ethiopia. In: Groundwater quality, 17th special report, (Nash, H. and McCall, G.J.H, eds). Chapman and Hall, London.

2. Birhanu Gizaw (1996). The origin of high bicarbonate and fluoride concentrations in waters of the main Ethiopian Rift Valley, East African rift system. Journal of African Earth Sciences 2:391-402.

3. Daniel Gemechu (1977). Aspects of Climate and Water Budget in Ethiopia. Addis Ababa University Press, $71 \mathrm{pp}$.

4. Darling, W.G. (1996). The Geochemistry of fluid processes in the eastern branch of the East African rift system, Ph.D, British Geological Survey, UK.

5. Darling, G., Birhanu Gizaw and Arusei, M. (1996). Lake-groundwater relationships and fluidrock interaction in the East African Rift Valley: isotopic evidence. Journal of African Earth Sciences 22:423-430.

6. Derje Ayalew, Gezahegn Yirgu and Pik, R. (1999). Geochemical and isotopic $(\mathrm{Sr}, \mathrm{Nd}$, and $\mathrm{Pb}$ ) characteristics of volcanic rocks from southwestern Ethiopia. Journal of African Earth Sciences 29:381-391.

7. Dissanayake, C.B. and Chandrajith, R. (1999). Medical geochemistry of tropical environments. Earth-Science Reviews 47:219258.

8. Fasil Tekola (2005). Economic cost of Podoconiosis in Wolaita Zone, Southern Ethiopia. Unpublished MSc Thesis. Addis Ababa University, $85 \mathrm{pp}$.

9. Fuge, R. and Johnson, C.C. (1986). The geochemistry of iodine a review. Environment Geochemistry and Health 8:31-54.

10. Gezahegn Yirgu, Dereje Ayalew, Peccerillo, A., Barberio, M.R., Donati, C. and Donato, P. (1999). Fluorine and chloride distribution in the volcanic rocks from the Gedemsa volcano,
Ethiopian Rift Valley. Acta Vulcanologica 2:169-176.

11. Harvey, R., Powell, J.J. and Tompson, R.P.H. (1996). A review of the geo-chemical factors linked to podoconiosis. In: Environmental Geochemistry and Health, pp. 25-260, (Appleton, JD, Fuge, R. and McCalll, G.J.H., eds). Geological Society Special Publication, UK No 113.

12. Kilham, P. and Hecky, R.E. (1973). Fluoride: Geochemical and ecological significance in east African waters and sediments. Limnology: 932-945.

13. Ministry of health/United Nations Children's Fund (1995). Nutrition policy: The miracle of iodated salt, Ethiopia's commitment to salt iodation. Joint Report on Situation Analysis, Addis Ababa, Family Health Department, MOH. 1995.

14. Pik, R., Deniel, C., Coulon, C., Gezahegn Yirgu, Hofmann, C. and Dereje Ayalew (1998).The north-western Ethiopian Plateau flood basalts: Classification and spatial distribution of magma types. J. Volcanol. and Geothermal Res. 81:91-111.

15. Price, E.W. (1974). The relationship between endemic elephantiasis of the lower legs and the local soils and climate. A study in Wollamo District, Southern Ethiopia. Trop. Geogr. Med. 26:225-230.

16. Price, E.W. (1976). The association of endemic elephantiasis of the lower legs in East Africa with soil derived from volcanic rocks. Trans. Royal Soc. Tro. Med. and Hygine 70:288-295.

17. Reimann, C., Bjorvatn, K., Frengstad, B., Zenebe Melaku, Reda Tekle-Haimanot, and Siewers, U. (2003). Drinking water quality in the Ethiopian section of the East African Rift Valley, part I: data and health aspects. The Sci. Tot. Env. 311:65-80.

18. Rozanski, K., Araguas-Araguas, L. and Gonfiantini, R. (1996). Isotope patterns of precipitation in the East African Region. In: The Climatology, Palaeoclimatoloy Oceanog. 18, Paleoecology of the East African Lakes, pp. 79-93, (Johnson, T.C. and Odada, E., eds). Gordon and Breach, Toronto.

19. Seifu Kebede (1999). The Hydrology and Hydrochemistry of Bishoftu Crater Lakes. Hydrological and Isotope Modeling. MSc Thesis, Addis Ababa University, Ethiopia.

20. Seifu Kebede (2004). Approaches isotopique et geochimique pour l'etude des eaux souterraines et des lacs: exemples du haut bassin du Nil Bleu et du rift Ethiopian. PhD Dissertation, University of Avignon, France.

21. Seifu Kebede, Travi, Y., Tamiru Alemayehu and Tenalem Ayenew (2005). Groundwater 
recharge, circulation and geo-chemical evolution in the source region of the Blue Nile River, Ethiopia. Applied Geochemistry 20:16581676.

22. Seifu Kebede, Travi, Y and Stadler, S. (2010). Groundwaters of the Central Ethiopian Rift: Diagnostic trends in trace elements. Environ. Earth Sci. DOI 10.1007/s12665-010-0479-5.

23. Tato Kebede (1964). Rainfall in Ethiopia. Ethiopian Geography Journal 2:28-36.

24. Tesfaye Chernet, Travi, Y. and Valles, V. (2001) Mechanism of degradation of the quality of natural water in the lakes region of the Ethiopian Rift Valley. Water Research 35:2819 2832.

25. Von Damm, K.L and Edmound, J.M. (1984). Reverse weathering in the closed basin lakes of the Ethiopian Rift. Am. J. Sci. 84:835-862.

26. WHO (2006) Guidelines for Drinking-Water Quality, Vol. 1, $3^{\text {rd }}$ ed., incorporating $1^{\text {st }}$ and $2^{\text {nd }}$ addenda. World Health Organization, Geneva.http://www.who.int/water_sanitati on_health/dwq/gdwq3rev/en/print.html. 